\title{
Comparative analysis of restoration behavior of milo (104A, 401A) and maldandi (M31-2A) based male sterile lines in sorghum [Sorghum bicolor (L.) Monech]
}

Lokesh Kumar Verma Kumar Verma ( $\nabla$ vermal@uasd.in )

University of Agricultural Sciences Dharwad

B. D. Biradar

UAS Dharwad: University of Agricultural Sciences Dharwad

S. S. Patil

UAS Dharwad: University of Agricultural Sciences Dharwad

S. N. Chattannavar

UAS Dharwad: University of Agricultural Sciences Dharwad

V. S. Kubsad

UAS Dharwad: University of Agricultural Sciences Dharwad

\section{Short Report}

Keywords: milo, maldnadi, 104A, 401A, M31-2A, fertility restoration

Posted Date: October 19th, 2021

DOI: https://doi.org/10.21203/rs.3.rs-850794/v1

License: @ (i) This work is licensed under a Creative Commons Attribution 4.0 International License. Read Full License

Version of Record: A version of this preprint was published at Genetic Resources and Crop Evolution on January 18th, 2022. See the published version at https://doi.org/10.1007/s10722-021-01324-z. 


\section{Abstract}

In sorghum, milo source of male sterility has been used for developing all the hybrids so far and it created the narrow cytoplasmic base. In addition, it also narrows down the nuclear diversity which may be the invitation for the outbreak of pests and diseases in the near future. To handle this hazard new diverse sources like $A_{2}, A_{3}, A_{4}$, maldandi, $V Z M$ and $G_{1}$ have been discovered. The availability of restorers on these sources is very difficult hence their utilization is also a challenging task. The present study was, therefore, carried out to test different sorghum lines for restoration behavior on two milo lines (104A and 401A) and one maldandi (M31-2A) with more emphasis on maldnadi source because of its added advantage of enhancing grain size and pest tolerance. In rabi-2017, 125 genotypes were tested for the restoration behavior on these sources, and five restorers viz., IS 19389, IS 995, IS 28389, IS 26046 (BRJ 67 - 8) and DSMR-8 restored fertility on 104A, two lines viz., IS 29335 and IS 26046 restored on $401 \mathrm{~A}$, while on M31-2A six lines viz., IS 19975, BRJ-67-4 (DSMR-4), BRJ 67 - 8 (DSMR-8), BRJ 67 - 16, BRJ 67 - 19, BRJ 67 - 21 restored the fertility. only two lines DSMR-8 and DSMR-4 exhibited stable, consistent and strong restoration (>90\% seed set) across the seasons (rabi-2017 and kharif-2017) and years (2017 and rabi-2018). All the used MS lines exhibited the restoration complexity in the following order $-104 \mathrm{~A}<401 \mathrm{~A}<\mathrm{M} 31-2 \mathrm{~A}$.

\section{Introduction}

Sorghum [Sorghum bicolor (L.) Monech] is the fifth major cereal crop of the world following wheat, rice, maize, and barley in terms of production and utilization. Sorghum grain is a dietary staple for millions of people in semi-arid areas of Asia and Africa where drought stress causes frequent failures of other crops. In Africa and Asia, sorghum grain is mainly used as food, while in the United States and Australia it is used to feed cattle (Reddy et al., 2013). Due to its versatile use as a source of food, feed, fodder and fuel, it is under cultivation in tropical, subtropical and even in temperate regions of the world as great millet. The world's sorghum production of 57.50 million tonnes comes from the area of $40.28 \mathrm{~m}$ ha with the productivity of 1.43 tonnes per hectare during 2019-20 (Foreign Agricultural Service/ USDA, 2020).

All the hybrids released commercially to date share the same sterile cytoplasm of milo, discovered by Stephens and Holland in 1954 . This situation can be an invitation for huge damage in the near future as evidenced by the repeated use of Texas cytoplasm in maize (Levings, 1990).

Many researchers have reported that most of the lines show the fertile reaction on milo $\left(\mathrm{A}_{1}\right)$ male sterile source, hence is easy compared to others for hybrid production. The new diverse sterile cytoplasmic sources viz., $\mathrm{A}_{2}, \mathrm{~A}_{3}, \mathrm{~A}_{4}$, maldandi, $\mathrm{VZM}$ and $\mathrm{G}_{1}$ were identified to overcome the threat of narrow cytoplasmic base. Due to the complex mechanism of restoration on non-milo cytoplasms, the restoration is difficult and research is also lacking in this area. Kishan and Borikar (1989) concluded that most of the genotypes from the Indian programme give a restorer reaction against milo cytoplasm thus, identification of suitable restorer for milo $\left(\mathrm{A}_{1}\right)$ cytoplasm is quite easy. However, the milo shows poor grain quality, susceptibility to shoot fly, poor fertility restoration in hybrids under rabi environment. The $A_{2}, A_{3}$ and $A_{4}$ cytoplasm are the available sources but for this, restoration appeared difficult. Because of these limitations, $A_{2}, A_{3}, A_{4}$ and other cytoplasmic male sterile lines have not been used for commercial exploitation. Use of indigenous maldandi source of male sterility, instead of exotic milo appears to be the best option. But there are no stable and consistent fertility restorers on this cytoplasm. Hence the present study was undertaken to identify the strong and stable restorers across the seasons and years.

\section{Material And Methods}

A total of 125 genotypes, comprising 68 (Set-I) and 57 (Set-II) were used as the pollen parents (Table $1 \& 2$ ). The Set-I is a part of minicore and the Set-II is comprised of derived lines of mutation treatment of BRJ-67 and BRJ-198. The fertility restoration of both sets was assessed on two MS lines of milo $\left(\mathrm{A}_{1}\right)$ viz., 104A \& 401A and one maldandi $\left(\mathrm{A}_{4 \mathrm{M}}\right)$ viz., M31-2A. A set of 204 crosses [(68 +57$) \times 3$ CMS lines] were developed during summer and kharif season of 2017.

The experiment was conducted at Botany Garden, Agriculture college, UAS, Dharwad during rabi-2017, kharifi-2018 and rabi-2018. Each hybrid was evaluated in a single row of 3 meters with an intra-row spacing of $15 \mathrm{~cm}$ and inter row spacing of $45 \mathrm{~cm}$. The hybrid plants were covered with brown paper bags to avoid cross pollination at physiological maturity. Selected panicles were harvested, observed physically for seed set and per cent seed set was calculated using the following formula (Kishan and Borikar, 1989)

Seed set per cent $=\frac{\text { Total number of seeds/panicle }}{\text { Total number of spikelets } / \text { panicle }} \times 100$

Based on the seed set per cent the genotypes were grouped into different categories of restoration as described by Biradar et al. (1996).

\section{Results And Discussion}

\section{Set-l: Fertility restoration behavior of minicore genotypes}

In set-I, out of 68 hybrids generated by crossing with the first milo based CMS line (104A), 15 crosses exhibited satisfactory (>60 \%) seed setting, while 20 hybrids were lacking in seed setting and characterized as perfect maintainers (Table 3). Four genotypes viz., IS 19389, IS 995 , IS 
28389 and IS 26046 were characterized as strong restorers as they exhibited $97.99 \%$ mean seed set. Nearly 35 per cent of lines were found to be partial restorers and have an average seed set per cent of 23.82. The mean seed set percentage of moderate restorers (9) was 71.22 per cent. Nine lines showed low restoration with the mean seed set per cent of 4.89. Of the 68 hybrids obtained by crossing with the second milo based CMS line (401A), 14 hybrids showed greater than 60 per cent seed set, while 19 hybrids showed no seed set and turned to be perfect maintainers. Only two genotypes, IS 29335 and IS 26046 were recorded as strong restorers and showed a $94.69 \%$ mean seed set. The highest proportion of the lines (31.34\%) were found to be partial restorers with an average 24.28 per cent seed set. A total of 11.94 per cent (8) of the total lines evaluated were moderate restorers and revealed 69.47 per cent seeds set. Thirteen lines exhibited low restoration with a mean seed set of 6.81 per cent. Only two hybrids, out of 68 , exhibited more than 60 per cent seed setting on selfing on the maldandi male sterile line and only one line IS 19975 was found to be a strong restorer with 100 per cent seed set. The highest proportion of the lines $(72.06 \%)$ were turned to be perfect maintainers and were lacking in seed set. Only one line was recorded as the moderate restorer with a 61.54 per cent seed set. Eleven and six genotypes were found to be partial restorers $(22.79 \%)$ and low restorers $(4.74 \%)$, respectively.

The present study revealed the complex behavior of restoration on maldandi compared to the milo. If we compare all the CMS lines used in the order of complexity for the availability of restorers it would be 104A < 401A < M31-2A, whereas the complexity for the availability of perfect maintainers would be $\mathrm{M} 31-2 \mathrm{~A}<401 \mathrm{~A}<104 \mathrm{~A}$.

\section{Set-II: Fertility restoration behavior of derived lines of BRJ-67 and BRJ-198.}

Of the 57 hybrids, 104A (milo), a total of 48 lines showed greater than 60 per cent seed set, whereas only one line turned to be perfect maintainers (Table 4). The strong restoration (91.68\%) was exhibited by only one genotype, (BRJ 67-8) DSMR-8. Around $54.39 \%$ of lines showed moderate restoration with a 74.05 per cent mean seed set. Partial restorers (8) exhibited mean seed set percentage of 49.13 and none of the lines showed low restoration. A total of 47 hybrids, on the second milo based CMS line (401A), showed more than 60 per cent seed set, whereas none of the lines were recorded as perfect maintainers. The strong restoration was not observed on 401A. The majority (38) of the lines were noticed as moderate restorers and exhibited $69.82 \%$ seed set. The mean seed set percentage of partial restorers (9) was $52.52 \%$. Only one line showed low restoration with mean seed set per cent of 7.87. The hybrids on maldandi male sterile line (M31-2A), 32 out of 57 hybrids exhibited greater than 60 per cent seed set on selfing. Out of these, five genotypes viz., BRJ-67-4 (DSMR-4), BRJ 67-8 (DSMR-8), BRJ 67-16, BRJ 67-19, BRJ 67-21 were considered as strong restorers as they restored an average 94.29 per cent fertility. The highest proportion of the lines $35.09 \%$ were found to be perfect maintainers with a zero per cent seed set. Fifteen lines were recorded moderate restorers with 70.85 per cent seed set. Two and three lines were turned to be partial and low restorers with 27.18 and 4.66 per cent seed set, respectively.

Across two sets, only one line viz., DSMR-8 restored the fertility on both milo and maldandi male sterile lines. This indicates that the restorers on maldandi may not always restore the fertility on milo. Overall the study indicates that restoration on maldandi male sterile line is complex compared to milo and between two milo lines viz., 104A and 401A, the 401A is more complex compared to 104A. Further from the two sets, 18 lines (Table 5) were selected and repeated testing was made during kharif-2018 and rabi-2018. Across three seasons two lines viz., DSMR-8 and DSMR-4 (Table 6) were found very strong restorers across two cytoplasm and three lines.

\section{Conclusion}

In this experiment, a greater number of restorers were recorded for 104A and 401A which had the blood of milo system, revealing the easy availability of restorers for this system compared to maldandi system. All the CMS lines used for this study would be in the order of $104 \mathrm{~A}<401 \mathrm{~A}<$ M31-A for the complexity of the availability of restorers and for perfect maintainers the order would be M31-2A $<401 \mathrm{~A}<104 \mathrm{~A}$.

\section{Declarations}

\section{Acknowledgements}

The author thanks Dr. B. D. Biradar for providing the derived lines of BRJ-67 and BRJ-198 and ICRISAT for providing the minicore germplasm lines of sorghum.

\section{Competing interests}

The authors declare that they have no competing interests.

\section{References}

1. Anonymous (2020) Food and Agricultural Organization of the United Nations, STAT Citation. http://www.faostat.fao.org

2. Biradar BD (1996) Genetic studies involving diverse sources of cytoplasmic genetic male sterility in sorghum [Sorghum bicolour (L.) Moench]. Ph.D Thesis, UAS, Dharwad

3. Kishan AG, Borikar ST (1989) Genetic relationship between some cytoplasmic male sterility systems in sorghum. Euphytica 42:259-269 
4. Levings CS (1990) The Texas Cytoplasm of Maize: Cytoplasmic Male Sterility and Disease Susceptibility. Science 250(4983):942-947

5. Reddy PS, Patil JV, Nirmal SV, Gadakh SR (2013) Improving post-rainy season sorghum productivity in medium soils: does ideotype breeding hold a clue. Curr Sci 102(6):904-908

6. Stephens JG, Holland DR (1954) Cytoplasmic male sterility for hybrid sorghum seed production. Agronomy J 46:20-23

\section{Tables}

Due to technical limitations, Tables 1 and 2 are only available as a download in the Supplemental Files section.

Table 3: Classification of restoration based on mean seed set per cent in minicore in rabi-2017

\begin{tabular}{|c|c|c|c|c|c|c|c|c|c|c|}
\hline \multirow{4}{*}{$\begin{array}{l}\text { Restoration } \\
\text { class }\end{array}$} & \multirow{4}{*}{$\begin{array}{l}\text { Seed set } \\
\text { per cent }\end{array}$} & \multicolumn{9}{|c|}{ Diverse sources of cytoplasm } \\
\hline & & \multicolumn{6}{|l|}{ Milo } & \multicolumn{3}{|l|}{ Maldandi } \\
\hline & & \multicolumn{3}{|l|}{$104 \mathrm{~A}$} & \multicolumn{3}{|l|}{$401 \mathrm{~A}$} & \multicolumn{3}{|l|}{ M31-2A } \\
\hline & & $\begin{array}{l}\text { No. of } \\
\text { genotypes }\end{array}$ & $\begin{array}{l}\text { Seed set } \\
\text { per cent }\end{array}$ & $\begin{array}{l}\text { Proportion } \\
\text { of lines }\end{array}$ & $\begin{array}{l}\text { No. of } \\
\text { restorers }\end{array}$ & $\begin{array}{l}\text { Seed set } \\
\text { per cent }\end{array}$ & $\begin{array}{l}\text { Proportion } \\
\text { of lines }\end{array}$ & $\begin{array}{l}\text { No. of } \\
\text { restorers }\end{array}$ & $\begin{array}{l}\text { Seed set } \\
\text { per cent }\end{array}$ & $\begin{array}{l}\text { Proportion } \\
\text { of lines }\end{array}$ \\
\hline $\begin{array}{l}\text { Strong } \\
\text { restoration }\end{array}$ & $>90 \%$ & 4 & 97.99 & 5.97 & 2 & 94.69 & 2.99 & 1 & 100 & 1.47 \\
\hline $\begin{array}{l}\text { High } \\
\text { restoration }\end{array}$ & $\begin{array}{l}80 \text { to } 90 \\
\%\end{array}$ & 2 & 86.29 & 2.99 & 4 & 85.23 & 5.97 & 0 & - & 0.00 \\
\hline $\begin{array}{l}\text { Moderate } \\
\text { restoration }\end{array}$ & $\begin{array}{l}60 \text { to } 80 \\
\%\end{array}$ & 9 & 71.22 & 13.43 & 8 & 69.47 & 11.94 & 1 & 61.54 & 1.47 \\
\hline $\begin{array}{l}\text { Partial } \\
\text { restoration }\end{array}$ & $\begin{array}{l}10 \text { to } 60 \\
\%\end{array}$ & 23 & 23.83 & 34.33 & 21 & 24.28 & 31.34 & 11 & 22.79 & 16.18 \\
\hline $\begin{array}{l}\text { Low } \\
\text { restoration }\end{array}$ & $<10 \%$ & 9 & 4.89 & 13.43 & 13 & 6.81 & 19.40 & 6 & 4.74 & 8.82 \\
\hline No seed set & $0 \%$ & 20 & 0.00 & 29.85 & 19 & 0.00 & 28.36 & 49 & 0.00 & 72.06 \\
\hline
\end{tabular}

Table 4: Classification of restoration based on mean seed set per cent in derived lines of BRJ-67 and BRJ-198 in rabi-2017

\begin{tabular}{|c|c|c|c|c|c|c|c|c|c|c|}
\hline \multirow{4}{*}{$\begin{array}{l}\text { Restoration } \\
\text { class }\end{array}$} & \multirow{4}{*}{$\begin{array}{l}\text { Seed set } \\
\text { per cent }\end{array}$} & \multicolumn{9}{|c|}{ Diverse sources of cytoplasm } \\
\hline & & \multicolumn{6}{|l|}{ Milo } & \multicolumn{3}{|l|}{ Maldandi } \\
\hline & & \multicolumn{3}{|l|}{$104 \mathrm{~A}$} & \multicolumn{3}{|l|}{$401 \mathrm{~A}$} & \multicolumn{3}{|l|}{ M31-2A } \\
\hline & & $\begin{array}{l}\text { No. of } \\
\text { genotypes }\end{array}$ & $\begin{array}{l}\text { Seed set } \\
\text { per cent }\end{array}$ & $\begin{array}{l}\text { Proportion } \\
\text { of lines }\end{array}$ & $\begin{array}{l}\text { No. of } \\
\text { restorers }\end{array}$ & $\begin{array}{l}\text { Seed set } \\
\text { per cent }\end{array}$ & $\begin{array}{l}\text { Proportion } \\
\text { of lines }\end{array}$ & $\begin{array}{l}\text { No. of } \\
\text { restorers }\end{array}$ & $\begin{array}{l}\text { Seed set } \\
\text { per cent }\end{array}$ & $\begin{array}{l}\text { Proportion } \\
\text { of lines }\end{array}$ \\
\hline $\begin{array}{l}\text { Strong } \\
\text { restoration }\end{array}$ & $>90 \%$ & 1 & 91.68 & 1.75 & 0 & - & 0.00 & 5 & 94.29 & 8.77 \\
\hline $\begin{array}{l}\text { High } \\
\text { restoration }\end{array}$ & $\begin{array}{l}80 \text { to } 90 \\
\%\end{array}$ & 16 & 85.11 & 28.07 & 9 & 84.03 & 15.79 & 12 & 84.56 & 21.05 \\
\hline $\begin{array}{l}\text { Moderate } \\
\text { restoration }\end{array}$ & $\begin{array}{l}60 \text { to } 80 \\
\%\end{array}$ & 31 & 74.05 & 54.39 & 38 & 69.82 & 66.67 & 15 & 70.85 & 26.32 \\
\hline $\begin{array}{l}\text { Partial } \\
\text { restoration }\end{array}$ & $\begin{array}{l}10 \text { to } 60 \\
\%\end{array}$ & 8 & 49.13 & 14.04 & 9 & 52.52 & 15.79 & 2 & 27.18 & 3.51 \\
\hline $\begin{array}{l}\text { Low } \\
\text { restoration }\end{array}$ & $<10 \%$ & 0 & - & 0.00 & 1 & 7.87 & 1.75 & 3 & 4.66 & 5.26 \\
\hline No seedset & $0 \%$ & 1 & 0.00 & 1.75 & 0 & - & 0.00 & 20 & 0.00 & 35.09 \\
\hline
\end{tabular}

Table 5: Selected lines identified as a restorer (>85\%) on M31-2A in rabi 2017 and $k$ harif-2018 


\begin{tabular}{|c|c|c|c|c|c|c|c|c|c|c|c|}
\hline \multirow{2}{*}{$\begin{array}{l}\text { S. } \\
\text { No. }\end{array}$} & \multirow[t]{2}{*}{ Genotypes } & \multicolumn{2}{|c|}{ Per cent restoration } & \multirow{2}{*}{$\begin{array}{l}\text { S. } \\
\text { No }\end{array}$} & \multirow[t]{2}{*}{ Genotypes } & \multicolumn{2}{|c|}{ Per cent restoration } & \multirow{2}{*}{$\begin{array}{l}\text { S. } \\
\text { No }\end{array}$} & \multirow[t]{2}{*}{ Genotypes } & \multicolumn{2}{|c|}{ Per cent restoration } \\
\hline & & Rabi-2017 & Kharif-2018 & & & Rabi-2017 & Kharif-2018 & & & Rabi-2017 & Kharif-2018 \\
\hline 1 & IS 19975 & 100.00 & 78.16 & 7 & BRJ-67 -3 & 84.92 & 58.37 & 13 & $\begin{array}{l}\text { BRJ-67 } \\
-30\end{array}$ & 83.76 & 82.73 \\
\hline 2 & BRJ-67 -8 & 99.58 & 99.36 & 8 & $\begin{array}{l}\text { BRJ-67 } \\
-25\end{array}$ & 89.56 & 84.61 & 14 & $\begin{array}{l}\text { BRJ-67 } \\
-15\end{array}$ & 82.89 & 75.16 \\
\hline 3 & BRJ-67 -4 & 95.70 & 96.81 & 9 & $\begin{array}{l}\text { BRJ-67 } \\
-27\end{array}$ & 87.60 & 82.08 & 15 & $\begin{array}{l}\text { BRJ-67 } \\
-10\end{array}$ & 82.33 & 78.62 \\
\hline 4 & $\begin{array}{l}\text { BRJ-67 } \\
-21\end{array}$ & 94.62 & 86.49 & 10 & $\begin{array}{l}\text { BRJ- } \\
67-18\end{array}$ & 88.90 & 83.60 & 16 & $\begin{array}{l}\text { BRJ-67 } \\
-22\end{array}$ & 81.35 & 69.46 \\
\hline 5 & $\begin{array}{l}\text { BRJ-67 } \\
-19\end{array}$ & 91.35 & 87.15 & 11 & $\begin{array}{l}\text { BRJ-67 } \\
-29\end{array}$ & 85.64 & 81.85 & 17 & $\begin{array}{l}\text { BRJ-67 } \\
-12\end{array}$ & 81.23 & 52.46 \\
\hline 6 & $\begin{array}{l}\text { BRJ-67 } \\
-16\end{array}$ & 90.18 & 86.24 & 12 & $\begin{array}{l}\text { BRJ-67 } \\
-20\end{array}$ & 85.36 & 79.59 & 18 & BRJ-67 -6 & 81.23 & 73.12 \\
\hline
\end{tabular}

Table 6: Consistent lines across the season for fertility restoration behavior against M31-2A in rabi-2018.

\begin{tabular}{|llllll|}
\hline S. No. & Restorer & M31-2A & S. No & Restorer & M31-2A \\
\hline 1 & BRJ-67-8 (DSMR-8) & 98.94 & 2 & BRJ-67-4 (DSMR-4) & 97.42 \\
\hline
\end{tabular}

\section{Supplementary Files}

This is a list of supplementary files associated with this preprint. Click to download.

- Table1and2.docx 